\title{
Front Matter: Volume 10216
}

, "Front Matter: Volume 10216," Proc. SPIE 10216, Smart Biomedical and Physiological Sensor Technology XIV, 1021601 (10 May 2017); doi:

$10.1117 / 12.2280845$

SPIE Event: SPIE Commercial + Scientific Sensing and Imaging, 2017, Anaheim, SPIE. CA, United States 


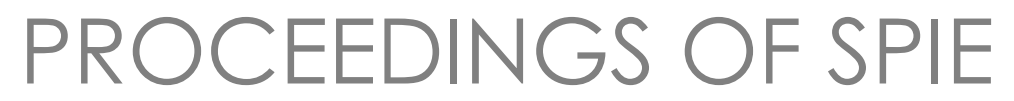

\section{Smart Biomedical and Physiological Sensor Technology XIV}

Brian M. Cullum

Douglas Kiehl

Eric S. McLamore

Editors

9-10 April 2017

Anaheim, California, United States

Sponsored and Published by

SPIE 
The papers in this volume were part of the technical conference cited on the cover and title page. Papers were selected and subject to review by the editors and conference program committee. Some conference presentations may not be available for publication. Additional papers and presentation recordings may be available online in the SPIE Digital Library at SPIEDigitallibrary.org.

The papers reflect the work and thoughts of the authors and are published herein as submitted. The publisher is not responsible for the validity of the information or for any outcomes resulting from reliance thereon.

Please use the following format to cite material from these proceedings:

Author(s), "Title of Paper," in Smart Biomedical and Physiological Sensor Technology XIV, edited by Brian M. Cullum, Douglas Kiehl, Eric S. McLamore, Proceedings of SPIE Vol. 10216 (SPIE, Bellingham, WA, 2017) Seven-digit Article CID Number.

ISSN: 0277-786X

ISSN: 1996-756X (electronic)

ISBN: 9781510609334

ISBN: 9781510609341 (electronic)

Published by

SPIE

P.O. Box 10, Bellingham, Washington 98227-0010 USA

Telephone +1 3606763290 (Pacific Time) · Fax +1 3606471445

SPIE.org

Copyright (c) 2017, Society of Photo-Optical Instrumentation Engineers.

Copying of material in this book for internal or personal use, or for the internal or personal use of specific clients, beyond the fair use provisions granted by the U.S. Copyright Law is authorized by SPIE subject to payment of copying fees. The Transactional Reporting Service base fee for this volume is $\$ 18.00$ per article (or portion thereof), which should be paid directly to the Copyright Clearance Center (CCC), 222 Rosewood Drive, Danvers, MA 01923. Payment may also be made electronically through CCC Online at copyright.com. Other copying for republication, resale, advertising or promotion, or any form of systematic or multiple reproduction of any material in this book is prohibited except with permission in writing from the publisher. The CCC fee code is 0277-786X/17/\$18.00.

Printed in the United States of America.

Publication of record for individual papers is online in the SPIE Digital Library.

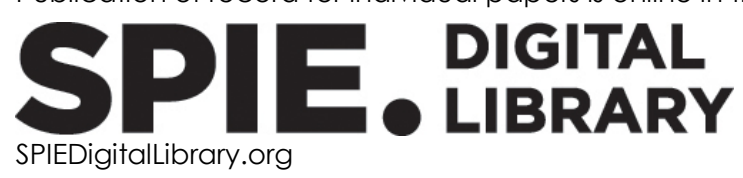

Paper Numbering: Proceedings of SPIE follow an e-First publication model. A unique citation identifier (CID) number is assigned to each article at the time of publication. Utilization of CIDs allows articles to be fully citable as soon as they are published online, and connects the same identifier to all online and print versions of the publication. SPIE uses a seven-digit CID article numbering system structured as follows:

- The first five digits correspond to the SPIE volume number.

- The last two digits indicate publication order within the volume using a Base 36 numbering system employing both numerals and letters. These two-number sets start with 00, 01, 02, 03, 04, $05,06,07,08,09,0 A, 0 B \ldots$. OZ, followed by 10-1Z, 20-2Z, etc. The CID Number appears on each page of the manuscript. 


\title{
Contents
}

\author{
$\checkmark$ Authors \\ vii Conference Committee
}

SESSION 1 BIOMOLECULAR SENSING AND VISUALIZATION

1021602 Biosensing via light scattering from plasmonic core-shell nanospheres coated with DNA molecules [10216-1]

1021605 The driving regulators of the connectivity protein network of brain malignancies [10216-4]

SESSION 2 ADVANCES IN HEALTH MONITORING TECHNOLOGY

1021606 Portable obstructive sleep apnea detection and mobile monitoring [10216-6]

1021607 Motion correction for improved estimation of heart rate using a visual spectrum camera [10216-7]

1021608 Reconfigurable wearable to monitor physiological variables and movement [10216-8]

SESSION 3 HEALTH APPLICATIONS OF MULTI-PARAMETRIC MODELING

1021609 Dynamical graph theory networks techniques for the analysis of sparse connectivity networks in dementia [10216-9]

10216 0A Parametric investigation of scalable tactile sensors [10216-12]

\section{SESSION 4 NEXT GENERATION ROBOTIC SENSING/MOTION}

10216 OB Optimal accelerometer placement on a robot arm for pose estimation [10216-13]

10216 OC Design and fabrication of an articulated four axes microrobot arm [10216-14]

10216 OD Mobile app for human-interaction with sitter robots [10216-17]

SESSION 5 REMOTE ROBOTIC SENSING/MONITORING

10216 OE Experimental setup for evaluating an adaptive user interface for teleoperation control [10216-18] 
10216 OF Fabrication of strain gauge based sensors for tactile skins [10216-19]

10216 OG Characterization of large-area pressure sensitive robot skin [10216-20] 


\section{Authors}

Numbers in the index correspond to the last two digits of the seven-digit citation identifier (CID) article numbering system used in Proceedings of SPIE. The first five digits reflect the volume number. Base 36 numbering is employed for the last two digits and indicates the order of articles within the volume. Numbers start with 00, 01, 02, 03, 04, 05, 06, 07, 08, 09, 0A, 0B...0Z, followed by 10-1Z, 20-2Z, etc.

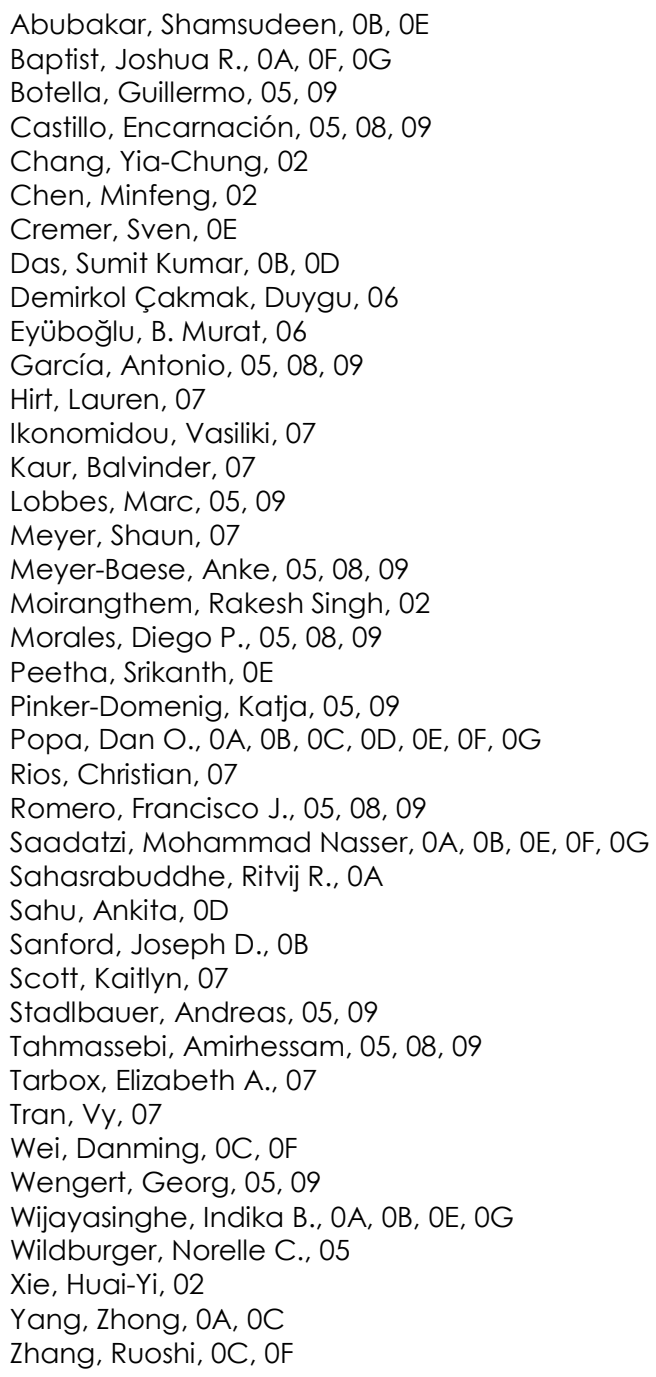


Proc. of SPIE Vol. $102161021601-6$

Downloaded From: https://www.spiedigitallibrary.org/conference-proceedings-of-spie on 26 Apr 2023 Terms of Use: https://www.spiedigitallibrary.org/terms-of-use 


\title{
Conference Committee
}

\author{
Symposium Chair
}

Majid Rabbani, Rochester Institute of Technology (United States)

Symposium Co-chair

Robert Fiete, Harris Corporation (United States)

Conference Chairs

Brian M. Cullum, University of Maryland, Baltimore County (United States)

Douglas Kiehl, Eli Lilly and Company (United States)

Eric S. McLamore, University of Florida (United States)

\section{Conference Program Committee}

Troy A. Alexander, U.S. Army Research Laboratory (United States)

Karl S. Booksh, University of Delaware (United States)

Liliana Braescu, University de Vest din Timisoara (Romania)

Jonathan C. Claussen, lowa State University (United States)

Mikella E. Farrell, U.S. Army Research Laboratory (United States)

Amethist S. Finch, U.S. Army Research Laboratory (United States)

Claudia Gärtner, microfluidic ChipShop GmbH (Germany)

Christopher D. Geddes, University of Maryland, Baltimore (United States)

Moinuddin Hassan, U.S. Food and Drug Administration (United States)

Ellen L. Holthoff, U.S. Army Research Laboratory (United States)

Ilko K. Ilev, U.S. Food and Drug Administration (United States)

K. D. Mandal, Institute of Technology, Banaras Hindu University (India)

T. Joshua Pfefer, U.S. Food and Drug Administration (United States)

Noriko Satake, UC Davis Medical Center (United States)

Shiv K. Sharma, University of Hawai'i (United States)

Narsingh B. Singh, University of Maryland, Baltimore County (United States)

Dimitra N. Stratis-Cullum, U.S. Army Research Laboratory (United States)

Mary E. Stuart, University of Maryland, Baltimore County (United States)

Michael Weinrich, National Institutes of Health (United States)

Ryan J. White, University of Maryland, Baltimore County

(United States) 
Session Chairs

1 Biomolecular Sensing and Visualization

Douglas Kiehl, Eli Lilly and Company (United States)

2 Advances in Health Monitoring Technology

Douglas Kiehl, Eli Lilly and Company (United States)

3 Health Applications of Multi-parametric Modeling Douglas Kiehl, Eli Lilly and Company (United States) Dan O. Popa, University of Louisville (United States)

4 Next Generation Robotic Sensing/Motion

Dan O. Popa, University of Louisville (United States)

Douglas Kiehl, Eli Lilly and Company (United States)

5 Remote Robotic Sensing/Monitoring

Douglas Kiehl, Eli Lilly and Company (United States) 